\title{
ON OPERATION OF 740 METRE LONG FREIGHT TRAINS ON CZECH TEN-T RAILWAY NETWORK
}

\author{
Michal DrábeK*, Vít Janoš, ZdenĚK Michl
}

\author{
Department of Logistics and Management of Transport, Faculty of Transportation Sciences, CTU in Prague, \\ Czech Republic \\ * corresponding author: xdrabek@fd.cvut.cz
}

\begin{abstract}
Regulation (EU) No 1315/2013 defines actual scope of core and comprehensive TEN-T network, including both networks for railway freight transport. For the core network, possibility to operate $740 \mathrm{~m}$ long freight trains is required. The aim of this paper is to analyse availability of appropriate overtaking tracks for $740 \mathrm{~m}$ long freight trains. Due to ETCS braking curves and odometry, such trains, after ETCS implementation, will require 780-800 m long overtaking tracks. For practical reasons (e.g. bypass lines), whole Czech railway TEN-T network is analysed. The overtaking track, whose occupation means influence on scheduled traffic or threat to boarding passengers, are excluded. The data was collected from station schemes from Collection of Official Requisites for 2015/16 Timetable, issued by SŽDC, Czech state Infrastructure Manager. Most of appropriate tracks are over $800 \mathrm{~m}$ long, but their density in the network and in particular directions varies considerably. For freight traffic, gradient of the line is important, so in the resulting figure, there are marked significant peaks for particular lines as well. Czech TEN-T lines are further segmented on the basis of number of tracks and their traffic character. Then, specific issues on overtaking or crossing of $740 \mathrm{~m}$ long freight trains are discussed. As a conclusion, for long-term development of Czech TEN-T lines, targeted investment is recommended not only for passenger railway, but also for freight railway. An attractive capacity offer for railway undertakings, which can stimulate freight traffic on European Rail freight corridors, can be represented by network-bound periodic freight train paths with suitable long overtaking tracks outside bottlenecks. After the overtaking by passenger trains, a freight train should run without stop through large node station or a bottleneck area. Before the sections with high gradients, coupling of additional locomotives should be connected with the overtaking process. Next suitable overtaking tracks should be available behind every significant peak of the line.
\end{abstract}

KEYWORDS: European freight corridor, long freight train, overtaking track, freight train path, peak .

\section{INTRODUCTION}

Directive 2008/57/EC of the European Parliament and of the Council of 17 June 2008 on the interoperability of the rail system within the Community [1] defines in Annex II infrastructure as a structural subsystem of the rail system, and traffic operation and management as a functional subsystem of the rail system. In the traffic operation and management subsystem, traffic planning is also included. Regulation (EU) No 1315/2013 of the European Parliament and of the Council [2] defines actual scope of core and comprehensive TEN-T network, including both networks for railway freight transport. For the core freight railway network, infrastructure requirements are defined. One of them is possibility to operate 740 m long freight trains. Regulation (EU) No 913/2010 of the European Parliament and of the Council of 22 September 2010 concerning a European rail network for competitive freight [3] defined 9 initial rail freight corridors (RFCs) across the EU. According to the Regulation, the corridors should provide guaranteed capacity for freight trains - "under good conditions in terms of commercial speed and journey times". The exact scope of each RFC are subject to negotiation by particular Member States. Three RFCs run directly through the Czech Republic: RFC 5 Baltic-Adriatic, RFC 7 Orient and RFC 9 Czech-Slovak. Moreover, negotiations about a branch of RFC 8 North SeaBaltic from Germany to Ústí nad Labem and Praha are proceeding. Present, as well as planned or negotiated RFCs are displayed in the official presentation of Czech Ministry of Transport by Kušnír and Ilík 4 . As a result, only few Czech TEN-T lines of comprehensive network are not included in any present RFC (or negotiated about being included in it). Because of possible future changes of RFCs layout, and because of practical need for bypass lines, the whole Czech railway TEN-T network was included in the analysis. Under the term "overtaking track" it is further understood any station track, which does not proceed any railway line in direct direction, i.e., it is not a main station track. For the sake of simplicity, the "not main" station tracks also in single-track lines, which serve mainly for crossing of trains, are referred to as "overtaking tracks". Usable length of an overtaking track (further referred to only as "track length") is defined as a distance between last departure main signals, each one for the opposite direction. In the 
case of group departure main signals (common for more parallel tracks), or absence of them, distance between last spots is considered, where rolling stock can be located, so that using of neighbouring track by another train is possible. The term "long trains" will be used for freight trains up to $740 \mathrm{~m}$ long. The term "long overtaking tracks" will be used for overtaking tracks at least $780 \mathrm{~m}$ long. For collection of data on length of overtaking tracks, railway station schemes from SŽDC (Czech state Infrastructure Manager) Collection of Official Requisites for 2015/16 Timetable [5] were used.

\section{Methods}

\subsection{Rules FOR Determination of Available Overtaking Tracks for 740 M LONG TRAINS}

The basic question is, how long overtaking track is sufficient for a $740 \mathrm{~m}$ long train. For present Czech signalling system and actual SŽDC regulations on traffic management, a track with additional $12 \mathrm{~m}$ length is sufficient. A $10 \mathrm{~m}$ distance is required between the locomotive and the departure main signal (in the train direction). The $2 \mathrm{~m}$ distance between an insulated gap and the departure main signal for the opposite direction is calculated. Brejcha and Čech [6] and Binko [7] [8], however, state that for the future ETCS implementation, a supplementary length of 40 to $60 \mathrm{~m}$ to the train length must be added, due to braking curve and inaccuracy of the ETCS odometry. On the basis of the facts stated above, the authors have decided to analyse two categories of available long overtaking tracks:

- 780 to 799 m long (in Figure 1, separate presence of such track or tracks in particular direction is marked in yellow colour)

- $800 \mathrm{~m}$ long and longer (in Figure 1 , presence of at least one such track in particular direction is marked in orange colour)

Presence of the tracks of both categories is marked in orange colour. Presence of at least one long overtaking track in particular direction (on the train's right, which is valid also for single-track lines or sections) is marked by obtuse-angled triangle of particular colour. Its obtuse angle lays in direction, which is this track preferably used for. On Czech railway network, there is only right-hand operation nowadays. In some recently modernized stations, an amended Czech Technical Standard TNŽ 342620 Railway Station and Line Signalling and Interlocking Systems [9] was implemented. For the through run routes with allowed speed over $120 \mathrm{~km} / \mathrm{h}$, if there is no flank protection from the overtaking track and this track is occupied, only "restricted run route" (VCO) with maximum speed $100 \mathrm{~km} / \mathrm{h}$ is allowed. This mandatory function of interlocking systems obviously leads to longer runtime for the fast train than scheduled. So, overtaking of freight trains on VCO-affected tracks is not desirable, but not critical. VCO-affected long overtaking tracks are marked by pink edge in Figure 1. For possible overtaking (or eventual crossing on single-track lines), only such overtaking tracks were considered, that did not lay between any main station track and waiting room (or entrance/exit of the station) in the case of at-grade access to platform (neither footbridge nor underpass). Also such overtaking tracks were not considered that were (or were supposed to be, based on actual timetable [5]) occupied by passenger trains to be overtaken, or turned around. In stations with sidings, an expert estimation of need of station tracks for the freight trains that start or terminate here, was carried out. However, even such "occupied" or "reserved" long overtaking tracks were recorded (separately), if they were long enough. But they are neither displayed if Figure 1 nor further discussed in this paper. In the case of a station with more yards (even a passenger and a freight yard), or with station tracks divided in the middle by switch region, an individual approach was chosen. If two subsequent tracks can be used by a long freight train without any impact on regular traffic, overall usable length of the resulting track was recorded. The Czech TEN-T lines will be further segmented into double-track lines, partially double-track lines and single-track lines. A triple-track line Poř́ččany - Praha-Libeň and rather short triple-track sections Bílina - Odb České Zlatníky and Hranice na Moravě - Drahotuše will be added to double-track lines. The double-track group comprises vast majority of Czech TEN-T railway network. These groups can be further divided into subgroups on the basis of their traffic character. The presence of absence of appropriate overtaking tracks will be discussed by particular segments of the lines.

\subsection{Where to Stop for Overtaking - A Soft Decision Process}

It is evident that any stop of a freight train in a bottleneck area leads to lower capacity utilization. So, overtakings should preferably be planned outside the bottlenecks. The following attributes of overtaking stations influence the quality of overtaking:

- Gradient on following line section (acceleration up the hill lengthens runtime of a freight train significantly and increases consumption of traction energy)

- Maximum allowed arrival speed on overtaking track (from the infrastructure viewpoint - it usually depends on arrival turnouts)

- Gradient on previous line section (braking downhill increases wear of brakes)

- Maximum allowable departure speed from overtaking track (usually depends on departure turnouts)

- Usable length of the longest overtaking track in particular direction 
In the authors' opinion, it is very difficult (if not impossible) to set an exact order of priorities of the attributes listed above. Each line, each passenger timetable and each set of freight trains together make a unique combination of specific conditions. So, a choice of the most suitable station for overtaking is always a soft decision process [10. Because of importance of gradients for freight railway, significant line peaks are also considered and marked in Figure 1 .

\section{Results And Discussion}

Czech TEN-T lines are further segmented on the basis of number of tracks and their traffic character. Presence or absence of long overtaking tracks is commented for each line group. For Přerov and Bohumín node stations, data on track length and on position of main departure signals were not available. Some interesting findings occurred. Firstly, during the analysis there emerged few theoretically suitable overtaking tracks which were approximately $770 \mathrm{~m}$ long. More precise calculations can determine the exact minimum practically usable track length for the long trains after implementation of ETCS. Secondly, most of the suitable overtaking tracks are over $800 \mathrm{~m}$ long. Unfortunately, their density in the network varies considerably.

\subsection{Double-Track (OR TRIPle-TRACK) LINES}

Busy national mainlines with mixed traffic:

- Praha - Česká Třebová - Olomouc - Přerov - Ostrava - Bohumín (- Chalupki) - Dětmarovice/Petrovice u Karviné (- Katowice) Třinec - Bystřice

Busy mainlines with significant (or prevailing) freight traffic:

- Praha - Děčín (- Dresden),

- Lysá nad Labem - Děčín Prostřední Žleb,

- Ústí nad Labem - Úpořiny - Bílina,

- Přerov - Břeclav (- Vienna/Bratislava),

- Bystřice - Mosty u Jablunkova (- Žilina).

Busy suburban sections with mixed traffic:

- Praha - Kralupy nad Vltavou,

- Praha - Lysá nad Labem - Nymburk - Kolín,

- Praha - Benešov u Prahy,

- Praha - Beroun,

- Brno - Tišnov,

- Brno - Skalice nad Svitavou,

- Brno - Břeclav.

Middle-busy mainlines:

- Ústí nad Labem - Teplice - Bílina - Most Chomutov - Karlovy Vary - Cheb (- Marktredwitz),

- Plzeň - Beroun,
- Kolín - Kutná Hora (station with both AC and DC traction power supply systems) - Havlíčkův Brod - Tišnov,

- Česká Třebová - Skalice nad Svitavou,

- Brno - Blažovice,

- Hranice na Moravě - Horní Lideč (- Žilina).

Due to practically exhausted capacity of the line Praha - Olomouc - Ostrava - Bystřice, freight trains should be able to run homogeneous train paths with a long-distance passenger train, so their maximum speed should be $120 \mathrm{~km} / \mathrm{h}$, in the worst case 100 $\mathrm{km} / \mathrm{h}$. The locomotives should be enough powered to accelerate the train to such speed before it has to be overtaken by next fast train. Even if such conditions are fulfilled, there are hardly any available train paths in morning and afternoon peaks between Praha and Česká Třebová. Because of busy traffic, the actual number of long overtaking tracks is not sufficient at all. Moreover, some ones are located in Kolín and Pardubice, the busiest nodes within the section mentioned above. For a freight train it is extremely complicate to find a train path that enables conflict-free departure from such busy nodes with level crossing of trains in various directions (e.g. fast train Praha - Havlíčkův Brod - Brno with non-stop express train Ostrava - Pardubice - Praha). The section Kolín - Lysá nad Labem is busy by suburban traffic, but enables homogeneous train paths even to slower freight trains (e.g. $90 \mathrm{~km} / \mathrm{h}$ ). However, any stop of a freight train in this section is highly undesirable, because the trains run in 5-8 min wide time slots after each other. Behind Lysá nad Labem, passenger traffic is considerably lower, but freight trains mostly do not need to stop because of train path homogeneity. In any case, the long trains should be scheduled early enough before a fast train, so that they could not delay them. Most freight trains need rear-end or head-end assistance in line sections with high gradients, e.g. Praha - Strančice, Český Těšín Čadca, Kutná Hora - Ždár nad Sázavou, Brno - Ždár nad Sázavou, Hranice na Moravě - Horní Lideč etc. For the long trains, $800 \mathrm{~m}$ long or longer overtaking tracks are desirable, because of length of the additional locomotive. It is appropriate to combine coupling and uncoupling of this locomotive with the overtaking process. Due to speed profile of the line Kralupy Děčín - Dresden, even $100 \mathrm{~km} / \mathrm{h}$ fast freight trains can run in homogeneous train paths with non-stop Eurocity trains. There is lack of long overtaking tracks in the direction from Praha. Practically, a non-stop train path from Praha-Holešovice to Děčín is required. On another lines of this sub-category, there is mostly almost no reason for the overtaking of freight trains, if the gradients are low. In busy suburban sections with mixed traffic, best capacity utilization means no stop of a freight train, which requires speed bundling (homogeneous train paths) either with suburban or with fast trains. 


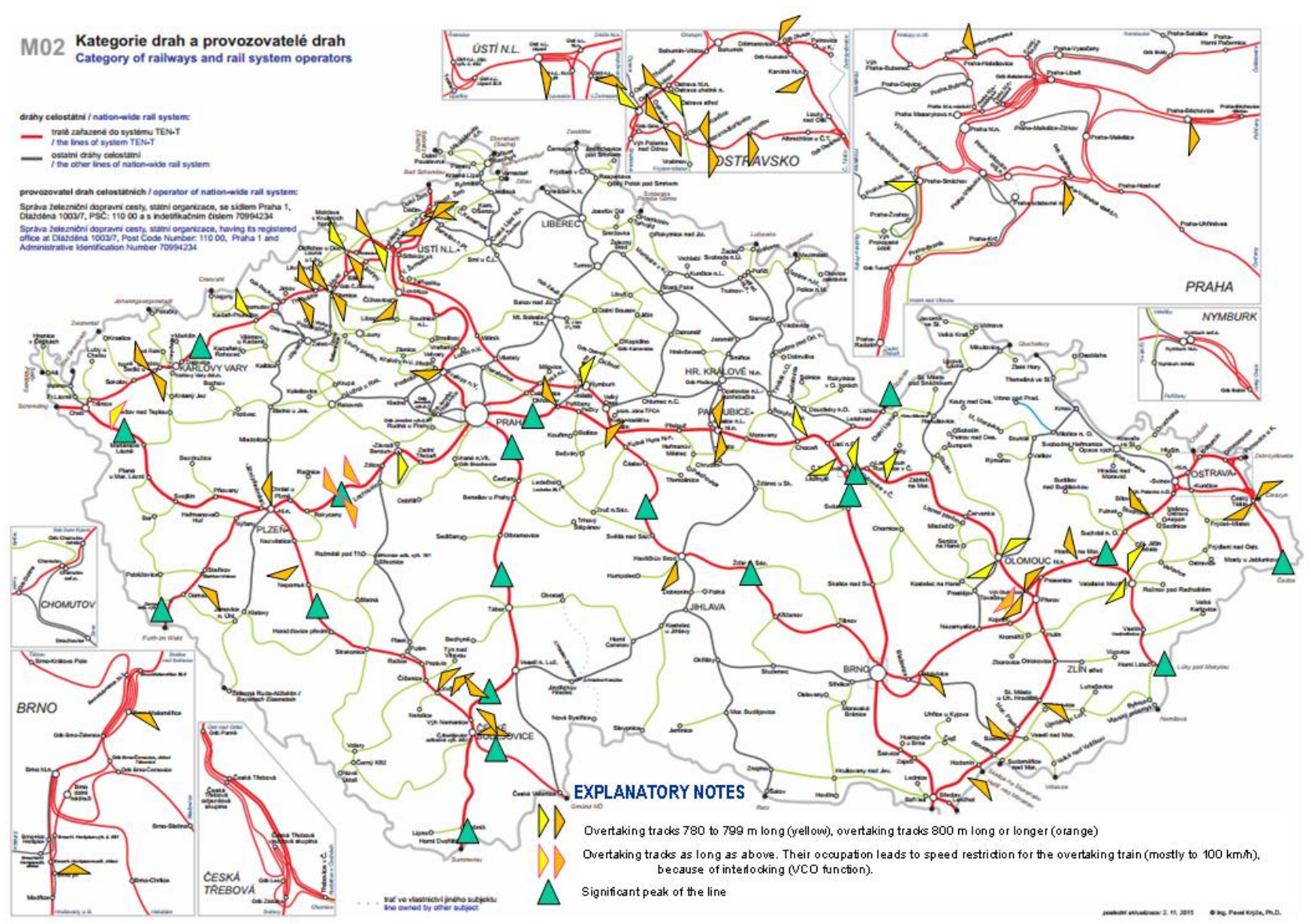

FiguRE 1. Presence of available long overtaking tracks in Czech TEN-T railway network. Map source: 11]

\subsection{Partially Double-track Lines (Middle-Busy Mainlines)}

- Plzeň - České Budějovice (with double-track sections Nepomuk - Horaždovice předměstí and Č́́čenice - Zliv),

- Benešov u Prahy - Tábor - České Budějovice (mostly double-track line, with remaining several single-track sections).

It is desirable to avoid crossing of the freight trains with trains of the opposite direction in single-track sections, because of necessity of stop. The line Benešov - České Budějovice has not much passenger traffic, but three significant peaks. Thus, double or triple traction for running through the whole line is worth consideration.

\subsection{Single-TRACK Lines}

Busy national mainlines with mixed traffic:

- Domažlice - Plzeň jižní předměstí,

- Brno - Holubice - Nezamyslice - Přerov.

Mainlines with significant freight traffic:

- České Budějovice - Horní Dvořiště (- Linz).

Middle-busy mainlines:

- Cheb - Plzeň (there are double-track sections Cheb - Lipová u Chebu and Pňovany - Plzeň only in ends of the line, so there is a character of a single-track line),

- (Furth im Wald) - Domažlice,

- Ústí nad Orlicí - Lichkov (- Wroclaw).

Mainlines with little traffic:

- České Budějovice - České Velenice (- Gmünd NÖ).

On single-track lines, longer overtaking tracks in almost every station are necessary, because of crossing of a freight train with any train which runs in the opposite direction. The alternative, which may be more efficient, is targeted partial doubling of the line. In the Czech Republic, most of passenger trains operate in (more or less) periodic timetable. If there are two systems of periodic passenger services with different section runtimes (and hence, with different crossing stations), there usually remains very little usable capacity left for freight trains. So, if there is a demand after a freight train paths approximately every 2 hours or more often, targeted partial doubling of the line is desirable. "Targeted" means in the sections where trains from opposite direction cross each other. For the passenger trains in the Czech Republic, it usually corresponds to "zero symmetry" time, i.e. the minute 00. Freight train paths should be, in the authors' opinion, if possible, designed as periodic with identic symmetry time, and meeting of the freight 
trains of the opposite direction should be designed into the planned double-track section. If the freight traffic is irregular, at least crossing of a freight and a passenger train should be designed there.

\subsection{Sections and Nodes with Lack of LONG OverTaking Tracks}

There are listed lines, sections or nodes where additional long overtaking tracks are desirable:

- Cheb - Plzeň,

- Furth im Wald - Domažlice - Plzeň,

- Plzeň - České Budějovice (a bypass line),

- Plzeň - Beroun - Praha (establishment of flank protection for long overtaking tracks can mostly solve the problem),

- České Budějovice - Horní Dvořiště (- Linz) (a bypass line),

- Praha - České Budějovice (a bypass line. After completed modernization, overtaking by fast trains is likely inevitable),

- Praha - Ústí nad Labem - Děčín (this direction only),

- Děčín Prostřední Žleb - Lysá nad Labem,

- Kolín - Havlíčkův Brod - Brno,

- Brno - Přerov (modernization of the whole line is planned),

- Praha - Olomouc (lack of long overtaking tracks outside large nodes),

- Přerov - Ostrava (this direction only),

- Brno - Břeclav (in the middle of the line and Břeclav freight yard).

\section{Conclusion}

Besides sections with high gradients, overtaking of a freight train is sometimes necessary because of fitting into spare time slot in a bottleneck area, or on a neighbouring line with a different timetable pattern. So, even on a line with sufficient capacity and train path homogeneity, a pair of long overtaking tracks is desirable for this reason. Another reason is preparedness for traffic disruptions. In the case of higher gradients, such track should lay behind the peak of the line and before beginning of higher gradient uphill section, but neither in busy node nor in suburban or another bottleneck area. The discussion above has shown that for fulfilling EU requirements for enabling operation of $740 \mathrm{~m}$ long freight trains, it is not necessary to lengthen overtaking tracks in every station on double-track lines. But such tracks are desirable outside bottleneck areas and, if need be, behind a peak of the line. For the freight railway undertakings, the probably best capacity offer would be system of periodic catalogue freight train paths without unnecessary stops, as proposed by Drábek [10, but with overtaking tracks long enough. This is the strategy that is recommended to SŽDC for long-term infrastructure improvement, as a conclusion of this paper.

\section{ACKNOWLEDGEMENTS}

The authors would hereby like to propose a vote of thanks to SŽDC for enabling them to use railway station schemes [5] and especially to propose a vote of thanks to its employee Dr. Pavel Krýže, who is the author of clearly arranged official maps of Czech Railway network 11. The authors were glad to use the mentioned sources for the research presented in this paper.

\section{REFERENCES}

[1] European Commission. Directive 2008/57/EC of the European Parliament and of the Council of 17 June, 2008 on the interoperability of the rail system within the Community [online], 2011.

http://eur-lex.europa.eu/legal-content/EN/TXT/ PDF/?uri=CELEX : 02008L0057-20110322\&from=EN

[2] European Commission. Regulation (EU) No. 1315/2013 of the European Parliament and of the Council of 11 December 2013 on Union guidelines for the development of the trans-European transport network and repealing Decision No. 661/2010/EU [online], 2013. http://eur-lex.europa.eu/legal-content/EN/ALL/ ?uri=uriserv:0J.L_.2013.348.01.0001.01.ENG

[3] European Commission. Regulation (EU) No.913/2010 of the European Parliament and of the Council of 22 September 2010 concerning a European rail network for competitive freight [online]. European Union, Brussels, 2010. http://eur-lex.europa.eu/legal-content/EN/ ALL/?uri=CELEX : 32010R0913.

[4] J. Kušnír, J. Ilík. Railway in 2030, Keynote speech, In: Future of Railway Passenger Transport in the Czech Republic, Czech Raildays [online], 2013. Ostrava: Czech Ministry of Transport, In Czech,

http://www.railvolution.net/czechraildays/2013/ seminare/konference-kusnir.pdf.

[5] SŽDC: Collection of Official Requisites for 2015/16 Timetable, Unpublished, Praha: SŽDC, 2015.

[6] R. Brejcha, R. Čech. Operation of Freight Trains Long up to $740 \mathrm{~m}$. In: Scientific-technical Proceedings of Czech Railways. Vol. 40/2015 [online], 2015. Praha: Czech Railways, In Czech, http://vtsb.cd.cz/VTS/CLANKY/vts40/4008.pdf

[7] M. Binko. Railway Infrastructure for Freight Transport, In Czech Raildays: Adaptation of Railway to both Actual and Future Transport Needs of Passengers and Goods [online], 2015. Praha: M-presse plus s.r.o., In Czech., http://www.railvolution.net/ czechraildays/2015/buletin2015.pdf.

[8] M. Binko. Railway Infrastructure for Freight Transport, Keynote speech, In Czech Raildays Conference [online], 2015. Ostrava: SŽDC s.o., [2015-06-16], In Czech, http://binko.webzdarma.cz/2015-6b.pdf.

[9] Czech Technical Standard TNŽ 342620 Railway Station and Line Signalling and Interlocking Systems, Amended, Effective since July 1. 2002, Unpublished, Olomouc: České dráhy, 2002.

[10] M. Drábek. Periodic Freight Train Paths in Network, Doctoral thesis. 2014. Praha: CTU in Prague, http://takt.fd.cvut.cz/cargo/Drabek_thesis.pdf

[11] P. Krýže. Maps of Railway Network [online], 2015. Praha: SŽDC, http://provoz.szdc.cz/PORTAL/ ViewArticle.aspx?oid=594598 